9. Плющ И. Г. Булавоусые чешуекрылые урбанизированных территорий Украинской ССР / И. Г. Плющ // материалы Х съезда Всесоюз. энтомол. общ. Успехи энтомологии в СССР. Насекомые перепончатокрылые и чешуекрылые : (11-15 сентября 1989 года). - Л., 1990. - С. 192-194.

10. Чиколовець В.В.Денні метелики України (фауністичний огляд) / В.В.Чиколовець // Зб. пр. Зоологічного музею. - Львів, 2005. - Вип. 37. - С. 13-62.

Теплюк Вадим, Кубат Наталия. Биоэкологический анализ бабочек семейств Papilionidae, Pieridae и Nimphalidae города Буськ и его окрестностей. Целью работы было уточнить видовой состав, установить относительную численность и провести комплексный биоэкологический анализ дневных бабочек. Исследованы основные природные биотопы (леса, луга) и агроценозы. Зарегистрирован 31 вид бабочек, которые разделены на группы в зависимости от относительной численности. Установлено биотопическую приуроченность, трофические связи гусениц, периоды лета имаго, особенности зимовки и развития отдельных видов. На лугах зарегистрированы 24 вида, а в лесах и агроценозах - по 20 видов в каждом. Среди вредителей сельскохозяйственных культур на стадии гусеницы отмечены P. brassicae, P. rapae, P. napi, P. daplidice. Зимует большинство видов (13) на стадии личинки. Лет бабочек начинается с середины марта и продолжается до середины октября. Одно поколение на год имеют 17 видов, два - 12 видов, более двух - 2 вида.

Ключевые слова: бабочки, гусеницы, биотоп, леса, луга, агроценозы.

Tepliuk Vadim, Kubat Natali. Bioecological analysis of Papilionidae, Pieridae and Nimphalidae butterflies families of the town Busk and its outskirts. The purpose of the work was to specify the species composition, to determine the relative abundance, to conduct a comprehensive bioecological analysis of day butterflies. The main natural habitats (forests, meadows) and agrocenoses were explored. 31 species butterflies were registered and they were divided into the groups depending on the relative abundance. Biotopical affiliation, trophic relations of caterpillars, flying period of adults, peculiarities of wintering and development of individual species were established. In meadows 24 species were registered and in the forests and agrocenoses there were 20 species in each. $P$. brassicae, $P$. rapae, $P$. napi, $P$. daplidice were marked as pests of agricultural crops in the caterpillar stage. The most of species (13) overwinters in larvae stage. The flying of butterflies begins from the middle of March and lasts until the middle of October. 17 species have one generation a year, 12 species have two, 2 species have more than two.

Key words: butterflies, caterpillars, habitat, forests, grasslands, agrocenoses.

Статя надійшла до редколегії 19.01.2015 p.

\title{
Павел Шекк
}

\section{Изменение видового состава ихтиофауны Хаджибейского лимана под действием антропогенных факторов и пути её целенаправленного формирования}

Хаджибейский лиман - высокопродуктивный водоём северо-западного Причерноморья. Под влиянием антропогенных факторов водоём последовательно превращался из полигалинного в мезогалинный олигогалинный - пресноводный и вновь в олигогалинный. Состав ихтиофауны и рыбопродуктивность лимана неоднократно изменялись в зависимости от гидролого-гидрохимического режима водоема, в первую очередь от солености вод. За последние 34 года в лимане встречалось до 21 вида рыб. Многие из них (калкан, угорь, осетр, густера, сом, глосса и др.) попали в лиман случайно либо в результате ограниченной интродукции и встречались редко, иногда единично.

В настоящее время лиман представляет собой солоноватоводный водоём-накопитель, что предполагает возможность целенаправленного формирования видового состава ихтиофауны.

Ключевые слова: Хаджибейский лиман, гидролого-гидрохимический режим, состав ихтиофауны, целенаправленное формирование.

Постановка научной проблемы и её значение. Лиманы и лагуны Причерноморья - высокопродуктивные естественные экосистемы. Благоприятный гидролого-гидрохимический режим, высокая температура воды, мелководность в сочетании с присутствием в составе флоры и фауны пресно-

(ㄱ) Шекк П., 2015 
водных, солоноватоводных и морских форм определяют биологическое разнообразие и высокую рыбопродуктивность этих водоемов[1-4].

Один из наиболее продуктивных водоемов северо-западного Причерноморья - Хаджибейский лиман. На пути своего исторического развития водоём пережил ряд периодов, последовательно превращаясь из полигалинного в мезогалинный - олигогалинный - пресноводный и вновь в олигогалинный водоем $[1 ; 2 ; 5 ; 6]$. Изменение солёности сопровождалось коренным изменением видового состава биоты лимана. Морскую ихтиофауну сменила солоноватоводная, а затем пресноводная [1-4; 7].

Сброс пресных вод с очистных сооружений г. Одессы в 60-х годах прошлого столетия привел к опреснению лимана, и с этого момента его гидролого-гидрохимический режим полностью зависит от объема сброса [1-4].

Для оценки современного состояния ихтиоценозов Хаджибейского лимана и прогноза дальнейших изменений, в составе ихтиофауны необходим мониторинг экосистемы водоёма, что позволит спрогнозировать возможные изменения в составе ихтиофауны и даст возможность целенаправленного формирования её состава.

Цель исследования - анализ факторов, влияющих на биоразнообразие ихтиофауны водоема, характеристика её современного видового состава и перспектив её целенаправленного формирования.

Материал и методика Сбор ихтиологического материала проводили на протяжении 1980-2014 гг. в разные сезоны года на всей акватории лимана. В период промысла материал отбирали из промысловых орудий лова (сети, волокуши, тралы). В запретный период - из контрольных орудий лова. Весь улов сортировали по видам. Фиксировали общую величину улова и соотношение в нем различных видов. Выборку, по 25-50 особей каждого вида, подвергали полному биологическому анализу [8]. Фиксировали соотношение отдельных видов в улове, распределение их по акватории лимана. Отбирали пробы для изучения питания рыб, определения возрастной структуры популяции. Весь полученый материал доставляли в лабораторию, где и проходила его обработка.

Видовой состав определяли при помощи определителей пресноводной и морской ихтиофауны $[9 ; 10 ; 11]$. В работе также использованы многолетние отчетные данные Одесского отделения ЮгНИРО и ихтиологической службы «Одессарыбвод», сообщения отдельных рыбаков и инспекторов службы государственной рыбоохраны о случаях достоверного вылова в акватории лимана редких видов рыб. При этом часто мы получали замороженный или зафиксированный материал, либо фотографии тех или иных объектов. Достоверность таких сообщений всегда тщательно проверялась.

Результаты исследования. Хаджибейский лиман расположен вблизи г. Одессы в долине реки Малый Куяльник. Это водоем закрытого типа, отделен от моря песчаной пересыпью шириной 4-5 км. Длина лимана - 40 км, ширина - от 0,8 до 3,5 км. Северная часть лимана более мелководная, южная - глубоководная. Максимальная глубина достигает 20-24 м, средняя - 4 м. В северозападной части лимана расположен Палиёвский залив, площадью 1000-1500 га, с глубинами до 5 м. В вершину залива впадает река Свиная [1-7].

Несмотря на сброс больших объёмов очищенных сточных вод, лиман является «слабозагрязненным» (умеренно загрязненным), а концентрация токсичных веществ в тканях и органах гидробионтов ниже ПДК $[4 ; 5]$.

Во второй половине XIX века ихтиофауна лимана была представлена морскими видами рыб (бычки и глосса), которые исчезли после полной изоляции от моря и осолонения водоема до 35 \%о.

В 30-х годах прошлого века после снижения солености до 16,7 \%о в лиман вселили креветку, глоссу и кефаль. С 1941 по 1944 г. в результате взрыва дамбы лиман соединился с морем, из которого в водоём зашли атерина, бычки, глосса, кефали и другие виды морских рыб [2-4; 7]. В послевоенные годы в лимане обитала камбала глосса, бычки: песочник и зеленчак. Дополнительно в водоём вселяют бычков: кнута и кругляка. Последующая изоляция водоема от моря сопровождалась осолонением лимана $[1 ; 2,12]$. В результате в лимане остаётся только три вида бычков и камбала глосса, которые и служили объектами промысла вплоть до 1970-х гг. Кроме бычков, в лимане в большом количестве добывали мидию и креветку.

Ещё в 50-е годы неоднократно предпринимались попытки интродукции в лиман сеголеток кефали (лобана, сингиля и остроноса) и камбалы калкана [13], однако эти попытки не увенчались успехом, хотя интродуценты выживали в водоёме и быстро росли.

Увеличение объемов сброса сточных вод привело к повышению уровня, опреснению и эфтрофикации водоёма [1-7]. В результате уже к 1975 г. полностью исчезли глосса, бычки (зеленчак и нигер), мидия, снизилась численность и уменьшились размеры креветки. 
К началу 80-х годов соленость вод лимана снизилась до 8-11 \%. В составе ихтиофауны появились карась, плотва, уклея, окунь, проникшие из прудов, расположенных в долине реки Малый Куяльник. Вместо обедневшего морского ихтиокомплекса активно формируется пресноводный.

В 1980 г. лиман впервые зарыбляют серебряным карасём (2 млн экз.), вместе с которым из Днестровского лимана и придунайских озерах завозят мальков леща, щуки, сома, густеры и других пресноводных рыб, а также раков.

В 1988 г. в лимане в садках успешно выращивают кефаль лобана и остроноса и сингиля [14], что показало возможность обогащения ихтиофауны водоёма за счет интродукции эвригалинных видов рыб.

Росту численности пресноводных рыб способствуют естественные нерестилища, расположенные в верховьях лимана (с. Белка) и Палиёвского залива (с. Егоровка), где ежегодно проходил массовый нерест карпа, карася, плотвы, щуки, судака, окуня и др.

В 1985 г. Палиёвский залив разделяют дамбами на три части. В средней части строится рыборазводный участок «Одесрыбхоза», где выращивают карпа, карася, белого и пестрого толстолобика, судака и окуня. Встречаются здесь также бычки: песочник, кругляк, зеленчак и тарань.

Дальнейшее зарегулирование Палиёвского залива дамбами и строительства пруда в его вершине приводит к обмелению и заилению, а отсутствие пресноводного стока - к прогрессирующему осолонению и потере нерестилищ. Уже в 90-е годы ихтиофауна вершины залива представлена только немногочисленным бычком - песочником, тугорослым карасем, трёхиглой колюшкой и мраморным бычком-лысуном. В то же время уловы в пределах рыбоводного участка «Одесрыбхоза» продолжают расти и в середине 90-х годов достигают максимума - 610-650 т (больше 1 т/га). Выращивание рыб здесь проводили при дополнительном кормлении. Ежегодно использовалось 20 40 тыс. тонн комбикорма, который высыпали на дно водоема (на кормовые площадки). Это приводит к прогрессирующей эфтрофикации. На дне залива образуется сероводородный слой. Ухудшению экологической ситуации способствуют периодические сбросы с навозохранилища Отрадовской птицефабрики.

Уже к 1990-1991 гг. наметилась стойкая тенденция к деградации центральной части залива. В 1992 г. в акватории рыбучастка снижаются уловы, замедляется рост рыб. В результате повышения солености и щелочности вод наблюдается массовое поражение карпа и растительноядных рыб краснухоподобным заболеванием.

В результате плохого водообмена с открытой акваторией лимана и отсутствием притока пресной воды происходит осолонение и пересыхание вершины и средней части Палиевской залива.

Соленость вод залива достигает 10-16 \%о и продолжает расти. Предпринимаются попытки интродукции в эту акваторию русского осетра, бычков - зеленчака и кругляка, а с 1992 г., в соответствии с нашими рекомендациями, - кефали пиленгаса, камбалы глоссы и камбалы калкана. Интродуценты хорошо прижились в акватории залива, успешно зимовали и хорошо росли.

Практически полное отсутствие естественного воспроизводства пресноводной ихтиофауны и сокращение, а потом и полное прекращение зарыбления карпом, растительноядными рыбами и карасем приводит к падению запасов и промышленных уловов в Хаджибейском лимане, которые достигают в 1995 г. минимума - 75 т.

Акклиматизации - в 1992 г. в Палиевском заливе, а затем и в открытой акватории Хаджибейского лимана - пиленгаса [15] способствует строительство на базе Палиёвского рыбучастка комплекса по воспроизводству морских рыб. Начиная с 1993 г., лиман ежегодно зарыбляется миллионами сеголеток и годовиков пиленгаса, полученных на этом рыбопитомнике [15; 16]. Уже к 2004 г. пиленгас натурализуется в лимане и формирует здесь самовоспроизводящуюся популяцию. Высокая численность и биомасса пиленгаса (а уже к 2000 г. этот вид занимает ведущее место в уловах) стимулирует рост численности судака, для которого мальки пиленгаса становятся основным объектом питания. При этом ослабевший пресс хищника на популяцию карася и бычков приводит также к росту их численности в лимане [16].

Таким образом, Хаджибейский лиман в результате хозяйственной деятельности человека преобразован в водоем-накопитель. Формирование его экосистемы зависит преимущественно от гидролого-гидрохимического и уровневого режима, которые поддерживаются искусственно. За последние 34 года (табл. 1) в лимане встречалось до 21 вида рыб. Многие из них (калкан, угорь, осетр, густера, сом, глосса и др.) попали в лиман случайно либо в результате ограниченной интродукции и встречались редко, иногда единично. Вместе с тем выживание, рост и зимовка в лимане этих объектов 
позволяет сделать вывод о соответствии условий обитания в водоёме их эколого-биологическим потребностям.

В последние годы (2013-2014 гг.) после повышения солености в заливе до 18-19 \%о здесь восстановилась популяция креветки. Изменившиеся условия обеспечили интенсивное воспроизводство, высокую численность и быстрый рост травяного шримса. За один сезон креветка достигает 4,5-7,0 см, а общий улов в заливе по экспертным оценкам составляет 3-6 т.

Необходимо отметить, что ихтиофауна водоема и его рыбопродуктивность в значительной степени формируется в результате интродукции различных видов рыб. Сегодня Хаджибейский лиман - солоноватоводный водоем, в равной степени пригодный для нагула некоторых пресноводных и солоноватоводных видов гидробионтов, что открывает путь к целенаправленному формированию ихтиофауны, обогащению её ценными промысловыми объектами.

Таблица 1

Видовой состав и распределение ихтиофауны в акватории Хаджибейского лимана

\begin{tabular}{|c|c|c|c|c|c|c|c|c|}
\hline \multirow{3}{*}{ Виды } & \multirow{2}{*}{\multicolumn{2}{|c|}{$\begin{array}{c}\text { Палиёвский } \\
\text { залив }\end{array}$}} & \multicolumn{6}{|c|}{ Хаджибейский лиман } \\
\hline & & & \multicolumn{2}{|c|}{$\begin{array}{c}\text { Верхняя } \\
\text { часть } \\
\end{array}$} & \multicolumn{2}{|c|}{$\begin{array}{c}\text { Середняя } \\
\text { часть } \\
\end{array}$} & \multicolumn{2}{|c|}{$\begin{array}{c}\text { Нижняя } \\
\text { часть }\end{array}$} \\
\hline & $\begin{array}{c}1980- \\
1995\end{array}$ & $\begin{array}{c}2000- \\
2014\end{array}$ & $\begin{array}{l}1980- \\
1995\end{array}$ & $\begin{array}{l}2000- \\
2014\end{array}$ & $\begin{array}{l}1980- \\
1995\end{array}$ & $\begin{array}{c}2000- \\
2014\end{array}$ & $\begin{array}{c}1980- \\
1995\end{array}$ & $\begin{array}{c}2000- \\
2014\end{array}$ \\
\hline 1 & 2 & 3 & 4 & 5 & 6 & 7 & 8 & 9 \\
\hline $\begin{array}{c}\text { Карп } \\
\text { Caprinus carpio L. }\end{array}$ & + & - & ++ & + & + & + & ++ & ++ \\
\hline $\begin{array}{c}\text { Толстолобик белый Hypophthalmichthys } \\
\text { molitrix Val. }\end{array}$ & + & - & ++ & ++ & + & ++ & ++ & ++ \\
\hline $\begin{array}{c}\text { Толстолобик пестрый Arisstichthys } \\
\text { nobilis Rich }\end{array}$ & + & - & + & ++ & + & ++ & ++ & ++ \\
\hline $\begin{array}{c}\text { Белый амур } \\
\text { Ctenopharingodon idella Val }\end{array}$ & + & - & + & + & + & + & ++ & + \\
\hline $\begin{array}{c}\text { Судак } \\
\text { Lucioperca lucioperca } L .\end{array}$ & ++ & + & ++ & ++ & ++ & ++ & ++ & ++ \\
\hline $\begin{array}{l}\text { Cом европейский } \\
\text { Silurus glanis } L\end{array}$ & - & - & + & - & - & - & - & - \\
\hline $\begin{array}{c}\text { Окунь } \\
\text { Perca fluviatilus } L \\
\end{array}$ & ++ & + & + & + & + & + & + & + \\
\hline $\begin{array}{c}\text { Лещ } \\
\text { Abramis brama L. }\end{array}$ & - & - & ++ & - & + & - & - & - \\
\hline $\begin{array}{c}\text { Карась серебряный } \\
\text { Carassius auratus Bloch }\end{array}$ & ++ & - & ++ & ++ & ++ & ++ & ++ & ++ \\
\hline $\begin{array}{c}\text { Густера } \\
\text { Blicca bjoerkna } L .\end{array}$ & - & - & + & - & - & - & - & - \\
\hline $\begin{array}{c}\text { Тарань } \\
\text { Rutilus rutilus hesheli Schlegel }\end{array}$ & + & - & + & - & - & - & + & - \\
\hline $\begin{array}{c}\text { Осетер русский Acipenser guldenstadti } \\
\text { Brandt }\end{array}$ & + & - & - & - & - & - & - & - \\
\hline $\begin{array}{c}\text { Бычок-травянник Gobius ophiocephalus } \\
\text { Pallas. }\end{array}$ & ++ & - & ++ & - & ++ & - & - & - \\
\hline $\begin{array}{c}\text { Бычок-песочник Neogobius fluviatilus } \\
\text { Pallas. }\end{array}$ & ++ & + & ++ & ++ & ++ & ++ & ++ & ++ \\
\hline $\begin{array}{c}\text { Бычок-кругляк Neogobius melanostomus } \\
\text { Pall. }\end{array}$ & ++ & - & + & ++ & ++ & + & + & + \\
\hline $\begin{array}{c}\text { Мраморный бычок-лысун } \\
\text { Pomatoshistus marmoratus Risso }\end{array}$ & ++ & + & ++ & ++ & ++ & ++ & ++ & ++ \\
\hline $\begin{array}{c}\text { Кефаль пиленгас } \\
\text { Liza heamatocheilus Temminck et } \\
\text { Schleger }\end{array}$ & ++ & ++ & ++ & ++ & ++ & ++ & ++ & ++ \\
\hline
\end{tabular}




\begin{tabular}{|c|c|c|c|c|c|c|c|c|}
\hline & & & & & & \multicolumn{3}{|c|}{ Закінчення таблиці } \\
\hline $\begin{array}{c}\text { Трехиглая колюшка } \\
\text { Gasterosteus aculeatus }\end{array}$ & ++ & + & ++ & ++ & ++ & ++ & ++ & ++ \\
\hline $\begin{array}{c}\text { Камбала калкан } \\
\text { Psetta maeotica Pall }\end{array}$ & + & - & - & - & - & - & - & - \\
\hline $\begin{array}{l}\text { Камбала-глоса Platichthys flesus luscus } \\
\text { Pall }\end{array}$ & + & - & - & - & - & - & - & - \\
\hline $\begin{array}{c}\text { Угорь европейский } \\
\text { Anguilla fnguilla }\end{array}$ & - & - & - & - & - & - & - & + \\
\hline Всего видов & 17 & 6 & 16 & 12 & 14 & 12 & 13 & 13 \\
\hline
\end{tabular}

Встречаються редко +

Многочисленные ++

Представляется целесообразной реакклиматизация в водоеме камбалы глоссы, продуктивность которой можно значительно увеличить за счет использования организмов зообентоса, креветки и мелких форм бычков.

Перспективными объектами культивирования в Хаджибейском лимане могут служить осетровые, представленные русским и ленским осетрами, а так же бестером.

Для повышения рыбопродуктивности водоема за счет бентофагов безусловно перспективна интродукция в лиман бычков: кругляка, кнута, нигера, бобыря и зеленчака.

Рациональное использование Палиевского залива - важнейшая составляющая в формирование биоразнообразия ихтиофауны и высокой рыбопродуктивности лимана. При этом первоочередная задача состоит в возобновлении свободного водообмена между заливом и открытой акваторией лимана. Улучшение гидролого-гидрохимического режима этой акватории позволит использовать ее как естественное нерестилище пиленгаса, глоссы, бычков и креветки.

Другим не менее привлекательным направлением развития аквакультуры в Палиевском заливе может служить выращивание калкана. Как показали исследования, проведенные в предыдущие годы, при нормализации водообмена и солености в пределах 8-14 \%о этот объект перспективен для культивирования.

Значительный интерес представляет возможность интродукции в Хаджибейский лиман лососевых рыб - стальноголового лосося и радужной форели. Благодаря высокой экологической пластичности эти виды отлично выживали в Шаболатском и Тилигульском лиманах и показали высокую потенцию роста в этих водоёмах. Поэтому интродукция их в Хаджибейский лиман, на наш взгляд, весьма перспективна.

Важное направление, которое следует развивать в акватории Хаджибейского лимана - искусственные рифы. Формирование биоты этих инженерных сооружений позволит не только значительно увеличить численность и продукцию некоторых видов рыб, например бычковых, но и улучшит экологическое состояние водоёма. Формирование на субстрате искусственных рифов колоний двухстворчатых моллюсков (мидии, мителястера и других гидробионтов) позволит значительно улучшить очистку вод лимана, повысит общую кормность водоема.

\section{Выводы.}

1. В разные годы изменение гидрологического режима и солёности вод Хаджибейского лимана сопровождалось коренной перестройкой видового состава биоты водоёма.

2. В настоящее время в результате хозяйственной деятельности человека лиман преобразован в солоноватоводный водоем-накопитель, формирование экосистемы которого в основном зависит от гидролого-гидрохимического и уровневого режима, которые регулируются искусственно.

3. За последние 34 года в лимане встречалось до 21 вида рыб, многие из которых (калкан, угорь, осетр, густера, сом, глосса и др.) попали сюда случайно либо в результате ограниченной интродукции и встречались редко, иногда единично

4. Лиман - солоноватоводный водоем, в равной степени пригодный для нагула как пресноводных, так и солоноватоводных видов гидробионтов, что открывает путь к целенаправленному формированию ихтиофауны, обогащению её ценными промысловыми объектами.

5. Перспективными объектами интродукции в Хаджибейский лиман могут служить: камбаловые, бычковые, осетровые и лососевые рыбы, а также креветка. 
6. Повышению биологической продуктивности и активизации процессов самоочистки будет способствовать строительство в акватории лимана искусственных рифов.

\section{Источники и литература}

1. Розенгурт М. Ш. Гидрология и перспективы реконструкции природных ресурсов одсских лиманов / М. Ш. Розенгурт. - Киев : Наук. думка. 1974. - 221 с.

2. Лиманно-устевые комплексы Причерноморья. Географически е основы хозяйственного освоения / под ред. Г. И. Швебса. - Л. : Наука, 1988. - 330 с.

3. Старушенко Л. И. Причерноморские лиманы одесщины и их рыбохозяйственное использование / С. Г. Бушуев. - Одесса : Астропринт, 2001.-151 с.

4. Северо-западная часть Черного моря: биология и экология. - Киев : Наук. думка. 2006. -701 с.

5. Журавлева Л. А. Режим минерального фосфора в воде водоемов Северного Причерноморья / Л. А. Журавлева // Гидробиология Дуная и лиманов Северо-Западного Причерноморья. - Киев : Нак. думка, 1986. C. $19-35$.

6. Журавлева Л. А. Гидрохимический режим / Л. А. Журавлева, Н. Г. Александрова // Лиманы Северного Причерноморья. - Киев : Наук. думка, 1990. - С. 29-69.

7. Шекк П. В. Формування іхтіофауни Хаджибейського лиману / П. В. Шекк, М. І. Крюкова // Таврійський науковий вісник. - Херсон, 2012. - Вип. 78. - С. 315-319.

8. Правдин И. Ф. Руководство по изучению рыб / И. Ф. Правдин. - М. : Пищевая пром-сть, 1966. - 376 с.

9. Световидов А. Н. Рыбы Черного моря / А. Н. Световидов. - М. ; Л. : Наука, 1964. - 551 с.

10. Мэйтленд П. С. Определитель пресноводных видов Европы : атлас рыб / П. С. Мэйтленд, К. Линсел, В. Сиделева. - СПб. : Амфора, 2009.- 287 с.

11. Мовчан М. Ю. Риби України / М. Ю. Мовчан. - К. : Золоті ворота, 2011. - 420 с.

12. Замриборщ Ф. С. Рыбы низовьев рек и приморских водоемов северо-западной части Черного моря и условия их существования : автореф. дис. ... д-ра биол. наук / Замриборщ Ф. С. - Одесса, 1965. -65 с.

13. Замриборщ Ф. С. Опыт промыслового выращивания кефали в Хаджибейском лимане / Ф. С. Замриборщ // Рыбное хозяйство. - 1952. - № 4. - С. 45-46.

14. Шекк П. В. Опыт контролируемого товарного выращивания кефалей во внутренних водоемах северозападного Причерноморья / П. В. Шекк, В. П. Бондарь, В. А. Малаховский // Рыбное хозяйство. - 1998. № 4. - C. 68-74.

15. Шекк П. В. Екологічні аспекти інтродукції далекосхідної кефалі піленгасу MUGIL SO-IUY (BASILEWSKY) у лимани північно-західного Причорномор'я / П. В. Шекк // Зб. наук. пр. Полтав. держ. пед. ун-ту. Серія : Екологія, біологічні науки. - Полтава, 2007. - Вип. 6 (58). - С. 109-115.

16. Шекк П. В. Биологически-технологические основы культивирования кефалевых и камбаловых рыб / П. В. Шекк. - Херсон : ЧП Гринь, 2012. - 305 с.

Шекк Павло. Зміна видового складу іхтіофауни Хаджибейського лиману під дією антропогенних факторів та шляхи їі цілеспрямованого формування. Хаджибейський лиман - високопродуктивна водойма північно-західного Причорномор'я. Під впливом антропогенних чинників зміни гідролого-гідрохімічного режиму послідовно перетворювали лиман із полігалінного в мезогалінний - олігогалінний - прісноводний і знов в олігогалінний. За останні роки в лимані траплялося до 21 виду риб. Багато з них (калкан, вугор, осетер, сом, глоса та ін.) потрапили в лиман випадково або в результаті обмеженої інтродукції. Водночас виживання, зростання і зимівля у лимані цих об'єктів дає змогу зробити висновок про відповідність умов водойми іх еколого-біологічним потребам.

Сьогодні лиман являє собою солонуватоводну водойму-накопичувач, що уможливлює цілеспрямоване формування видового складу іхтіофауни і розширення іï видового різноманіття за рахунок інтродукції цінних видів солонуватоводних і прохідних риб.

Ключові слова: Хаджибейський лиман, гідролого-гідрохімічний режим, видовий склад іхтіофауни, цілеспрямоване формування.

Shekk Pavel. Changes in Species Composition of Fish Fauna Hadzibeevsky Estuary Under the Influence of Anthropogenic Factors and Ways of its Purposeful Formation. Hadzibeevsky estuary highly productive reservoir north-west of the Black Sea. Under the influence of anthropogenic factors reservoir experienced a number of periods of consistently turning in poligalinnogo mesohaline - oligogaliny - freshwater and again in oligagalinny. The composition of the fish fauna and fish productivity Hadzibeevsky estuary repeatedly changed depending on the hydrological and hydrochemical regime of the water body and primarily on salinity. Over the last 34 years, in the estuary occurred up to 21 species of fish. Many of them (turbot, eel, sturgeon, bream, catfish, flounder, etc.). Got into the estuary by accident or as a result of the introduction of a limited and rare, sometimes singly and in limited quantities. 
At present, the estuary is a brackish body of water storage, which implies the possibility of purposeful formation of the species composition of the fish fauna. Promising targets cultivation Khadzhibey estuary include: flounder, sturgeon, salmon, gobies, shrimp. Important area of aquaculture in the estuary - artificial reefs.

Keywords: Khadzhibei estuary, hydrological and hydrochemical conditions, the composition of the fish fauna, purposeful formation.

Стаття надійшла до редколегії 16.02.2015 p.

УДК 595.142.3

\section{Леся Бусленко Леся Щепна}

\section{Структура комплексу дощових черв'яків родини Lumbricidae cipих лісових грунтів Волинської височини}

На перелогах формується комплекс люмбрицид, який у сірих лісових грунтах представлений 9-ма видами. На ранніх етапах їх природного заліснення збільшується чисельність підстилкових та грунтово-підстилкових видів.

Ключові слова: дощові черв'яки, люмбрициди, морфо-екологічні групи, сукцесія, перелоги, заліснення.

Постановка наукової проблеми та їі значення. Порушення природної врівноваженості процесів у біосфері в цілому, балансу поживних речовин у малому біологічному кругообігу спричинили погіршення еколого-агрохімічного стану грунтів. Важлива роль в стабілізації функціонування екосистем в умовах антропогенного навантаження належить грунтовим тваринам. Дощові черв'яки родини Lumbricidae, завдяки своїм високим адаптивним можливостям, є важливим ланцюгом у трансформації органічної речовини та в підтриманні екологічної стійкості грунтової біоти в умовах Волинської височини.

Вилучення деградованих і малопродуктивних земель з сільськогосподарського використання сприяє відновленню природного стану едафотопів. Сукцесійні процеси зумовлюють зміни структури грунтового покриву. Відповідно відбувається перебудова фауністично-екологічної структури люмбрицид як важливого компонента зооценозу.

Аналіз досліджень цієї проблеми. Екологічні аспекти поширення, формування, функціонування люмбрицид, їх генезис у грунтовому покриві висвітлено у наукових працях В. В. Іванціва [3; 4; 5]. У монографії «Структурно-функціональна організація комплексів грунтових олігохет західного регіону України» приділено увагу питанням перебудови угруповання дощових червів родини Lumbricidae при осушенні болотних грунтів, розорюванні алювіальних лучних грунтів, на рекультивованих торфових виробках [4]. Аналіз наукових публікацій з моніторингу перебігу сукцесійних змін, що відбуваються на перелогах, засвідчує актуальність проблеми встановлення закономірностей трансформації едафічного компонента, еколого-фітоценотичної структури, відновлення природного біорізноманіття в зооценозі $[1 ; 7 ; 8]$.

Мета нашого дослідження - вивчити структурні особливості дощових черв'яків родини Lumbricidae в сірих лісових грунтах біогеоценозів Волинської височини в сукцесійному аспекті.

Виклад основного матеріалу й обгрунтування отриманих результатів дослідження. Волинська височина характеризується розчленованістю територій в умовах більш високого підняття місцевості над рівнем моря (абсолютні висоти досягають 292 м). На підвищених елементах рельєфу на схилах залягають сірі лісові грунти, які утворились під широколистяними або мішаними лісами за участю трав'яної рослинності. Вони слабкогумусовані, ненасичені кальцієм, мають чітку диференціацію грунтового профілю. Сірі лісові грунти сформувались переважно на лесоподібних суглинках. Гранулометричний склад таких грунтів характеризується високим вмістом фізичної глини та низьким вмістом фізичного піску. Під час дощів поверхня грунту запливає, а при підсиханні утворюється кірка, яка негативно впливає на газовий режим грунтових організмів.

(С Бусленко Л., Щепна Л., 2015 